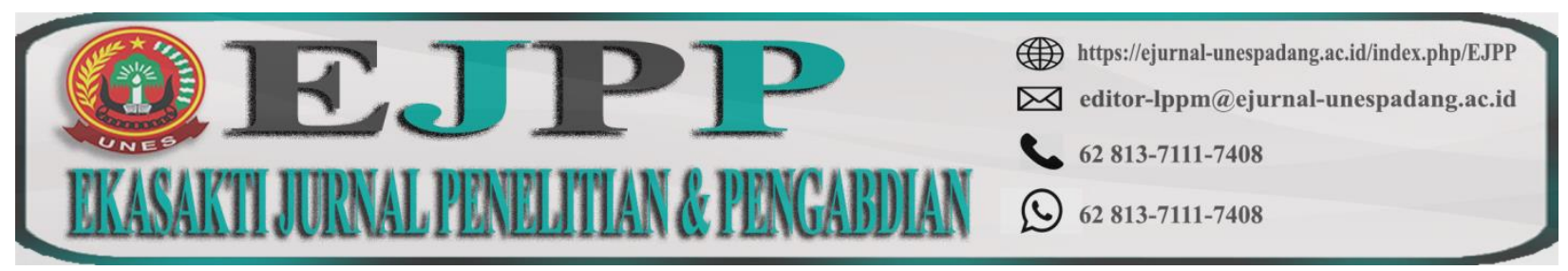

DOI: https://doi.org/10.31933/ejpp.v1i1

Received: 02/10/2020, Revised: 25/10/2020, Publish: 22/11/2020

\title{
KOMUNIKASI PROMOSI TANGKELEK PADA TEMA PRODUK DALAM MEMBANGUN PESAN TERHADAP KONSUMEN
}

\author{
Wahyuni Permata Sari, Dora Tiara, dan Kiki Yulinda \\ 1) Fakultas Ilmu Sosial dan Ilmu Politik, Universitas Ekasakti Padang \\ 2) Fakultas Ilmu Sosial dan Ilmu Politik, Universitas Ekasakti Padang \\ 3) Fakultas Ilmu Hukum, Universitas Ekasakti Padang
}

\begin{abstract}
ABSTRAK
Saat ini Kadai Tangkelek mulai dikenal luas oleh sebagian besar konsumen dari Kota Padang dan juga wisatawan baik domestik maupun mancanegara yang berkunjung ke Sumatera Barat. Konsep bisnis ini adalah kreatifitas dalam mengangkat budaya Minangkabau sebagai sebuah budaya yang kaya akan nilai-nilai positif kehidupan. Melihat kesuksesan dari usaha sejenis seperti produk Dagadu sebagai ikon Yogyakarta, serta produk Joger di Bali dengan tagline "Bali Bagus Joger Jelek" sukses menarik minat konsumen lokal dan bahkan internasional. Hal ini didukung dengan tingkat kunjungan wisatawan yang cenderung stabil dan meningkat di wilayah tersebut.

Metode penelitian pada penelitian menggunakan metode kualitatif. Penelitian kualitatif bertujuan untuk menjelaskan fenomena dengan sedalam-dalamnya. Riset ini tidak mengutamakan besarnya populasi atau sampling bahkan populasi atau sampling-nya sangat terbatas.

Dari berbagai upaya promosi yang dilakukan, media instagram menduduki peringkat pertama sebagai media yang berhasil menyampaikan pesan brand poduk kepada para pembeli. Hal ini terlihat dengan banyaknya followers instagram dari @ kadaitangkelek yang menyukai produkproduk yang diposting.Selain itu media berupa website dan facebook juga memiliki pengaruh yang cukup signifikan terhadap hasil penjualan produk Distro Tangkelek.
\end{abstract}

Kata Kunci: Komunikasi, Konsumen, Pesan, Promosi, Tangkelek.

\section{ABSTRACT}

Currently Kadai Tangkelek is starting to be widely recognized by most consumers from Padang City and also tourists both domestic and foreign who visit West Sumatra. This business concept is creativity in elevating Minangkabau culture as a culture that is rich in positive values of life. Seeing the success of similar businesses such as Dagadu products as an icon of Yogyakarta, as well as Joger products in Bali with the tagline "Bali Bagus Joger 
Jelek", they have succeeded in attracting local and even international consumers. This is supported by the level of tourist visits that tend to be stable and increasing in the region.

The research method in research using qualitative methods. Qualitative research aims to explain the phenomenon in depth. This research does not prioritize population size or sampling, even the population or sampling is very limited.

Of the various promotional efforts undertaken, Instagram was ranked first as a medium that succeeded in conveying product brand messages to buyers. This can be seen by the large number of Instagram followers of @ kadaitangkelekwho like the products posted. In addition, the media in the form of websites and Facebook also have a significant influence on the sales results of Tangkelek Distro products.

Keywords: Communication, Consumer, Message, Promotion, Tangkelek

\section{PENDAHULUAN}

Berawal dari kreativitas dan semangat melestarikan budaya Minangkabau sebagai modal utama, Fefri Rusji bersama rekannya Chalid Arafah membangun usaha dengan konsep unik. Kegiatan usaha yang berdiri sejak April 2009 ini merupakan tergolong jenis usaha baru pada saat itu di Kota Padang. Pada awalnya usaha ini mengusung konsep serupa yang telah berhasil dijalankan oleh Dagadu dan Joger. Dagadu merupakan brand kota Yogyakarta dengan mengangkat tema keunikan serta kehidupan masyarakat kotanya. Sementara Joger merepresentasikan keindahan bali dengan pelesetan kata-kata. Namun Kadai Tangkelek sedikit berbeda dari kedua brand tersebut, dimana sebagian besar produk-produknya menggunakan bahasa Minangkabau yang menjadi kebanggaan masyarakat Sumatera Barat.

Nama yang digunakan untuk usaha ini pada awalnya adalah Lamang Tapai. Nama ini diambil dari celetukan pemilik, dimana Lamang Tapai juga merujuk pada nama makanan yang terbuat dari ketan dan ubi yang difermentasi. Namun Lamang Tapai juga memiliki makna filosofis lain yakni sesuai dengan bentuknya yang lembek, hal ini cenderung melambangkan sesuatu yang lemah dan tidak berdaya. Disamping itu, makanan yang mudah hancur ini apabila jatuh maka tidak bisa dimakan atau dikonsumsi lagi.

Maka dari itu pemilik memutuskan untuk mengganti nama tersebut dengan Tangkelek. Tangkelek merupakan istilah yang digunakan oleh orang minangkabau untuk sendal kayu atau bakiak yang biasa digunakan oleh orang-orang dahulu terutama untuk pergi ke mesjid. Nama ini dipilih karena mengandung makna filosofis sebagai sesuatu yang kuat, keras, dan sifatnya yang tahan lama. Disamping itu bunyi tangkelek yang nyaring dan keras saat digunakan juga melambangkan bahwa nama ini akan selalu terdengar oleh siapa pun. Nama ini dirasa masih kurang sesuai untuk menggambarkan konsep usaha yang mengusung budaya lokal. Sehingga kemudian pada tahun 2012 pemilik memutuskan untuk mengganti istilah distro dengan kadai. Kadai sendiri merupakan bahasa minangkabau yang berarti toko atau warung yang menjual berbagai kebutuhan. Nama Kadai Tangkelek dianggap sangat tepat untuk menyelaraskan merek, konsep usaha, serta produk yang dijual yakni produk-produk kreatif yang dihasilkan dengan mengusung budaya minangkabau. 
Saat ini Kadai Tangkelek mulai dikenal luas oleh sebagian besar konsumen dari Kota Padang dan juga wisatawan baik domestik maupun mancanegara yang berkunjung ke Sumatera Barat. Konsep bisnis ini adalah kreatifitas dalam mengangkat budaya Minangkabau sebagai sebuah budaya yang kaya akan nilai-nilai positif kehidupan. Melihat kesuksesan dari usaha sejenis seperti produk Dagadu sebagai ikon Yogyakarta, serta produk Joger di Bali dengan tagline "Bali Bagus Joger Jelek" sukses menarik minat konsumen lokal dan bahkan internasional. Hal ini didukung dengan tingkat kunjungan wisatawan yang cenderung stabil dan meningkat di wilayah tersebut.

Tahun berikutnya usaha ini dikenal dengan Distro Tangkelek, untuk lebih memperjelas bahwa yang dijual di toko ini bukanlah sendal kayu melainkan pakaian dan aksesorisnya. Distro sendiri merupakan singkatan dari distribution store atau distribution outlet, yakni sejenis toko yang menjual pakaian dan aksesoris yang dititipkan atau diproduksi oleh produsen atau komunitas tertentu. Distro sendiri identik dengan produk-produk dari merek ternama luar negeri yang biasanya digandrungi oleh anak-anak muda. Pada awalnya target market produk Kadai Tangkelek hanyalah sebagai cinderamata wisatawan yang berkunjung ke Kota Padang. Dengan desain khusus yang dirancang oleh pemilik sekaligus desainer Fefri Rusji alumni Jurusan Seni Rupa Universitas Negeri Padang, produk dari Kadai Tangkelek bersifat orisinil dan terbatas (limited edition). Mengusung budaya Minangkabau mulai dari petatah petitih para leluhur, kebiasaan dalam kehidupan sehari-hari masyarakat Minangkabau, objek wisata dan kesenian tradisional Minangkabau, sampai dengan lelucon atau istilah yang saat ini tengah hangat dikalangan orang Minangkabau.

Melihat kesuksesan yang mampu diraih PT. Dagadu Aseli dan Joger sebagai brand icon yang menjadi ciri khas Yogya dan Bali, Kadai Tangkelek pun mencoba mengikuti jejak yang sama. Target pasar utama Kadai Tangkelek adalah wisatawan yang menjadikan produk-produk tersebut sebagai cinderamata untuk dibawa ke daerah asal. Terutama pasca gempa tahun 2009, kota Padang ramai didatangi oleh relawan yang berasal dari berbagai wilayah Indonesia, termasuk negara-negara tetangga yang juga mengirimkan bantuan.

Namun setelah masa bantuan dari para relawan telah selesai, berbagai sektor baik ekonomi, pemerintahan, dan lain-lain masih belum stabil. Hal ini turut berdampak pada sektor pariwisata dimana kunjungan wisatawan juga berkurang. Sehingga Kadai Tangkelek merasakan imbas dari ketidakstabilan kondisi tersebut. Untuk mengatasi hal ini, Kadai Tangkelek mulai menyesuaikan target pasar yang semula merupakan wisatawan, menjadi anak-anak muda yang berdomisili di kota Padang. Produk-produk Kadai Tangkelek pada saat itu masih kurang dikenal dan kurang diminati karena beberapa faktor, dan salah satunya adalah desain yang terkesan kaku karena menggunakan bahasa Minangkabau baku. Maka dari itu designer Kadai Tangkelek mulai berupaya untuk menciptakan desain yang lebih unik dan kreatif sesuai dengan selera pasar.

Sejak didirikan pada 14 April 2009 Kadai Tangkelek telah memproduksi lebih dari 800 desain hingga saat ini. Produk-produk yang dihasilkan dari Kadai Tangkelek adalah baju kaos, sweater atau jaket, serta beberapa asesoris seperti tas dan pin. Berikut ini contoh beberapa desain unik yang diproduksi Kadai Tangkelek : 


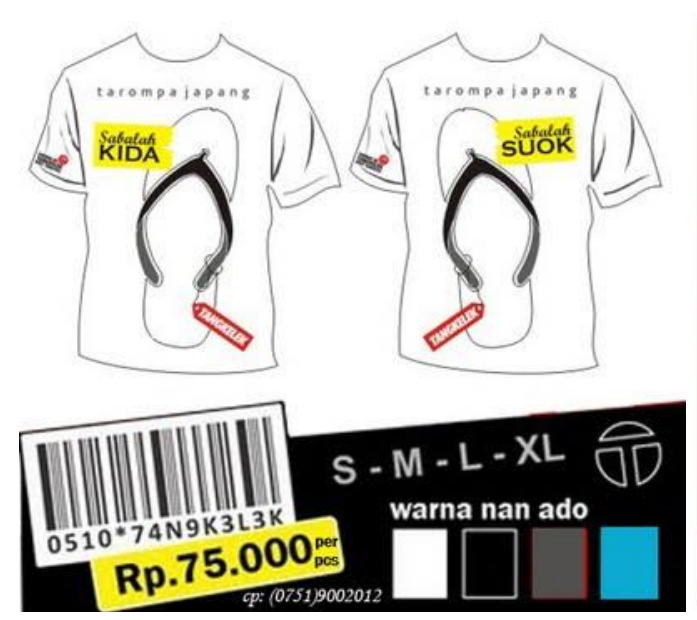

Sumber : www.tangkelek.com

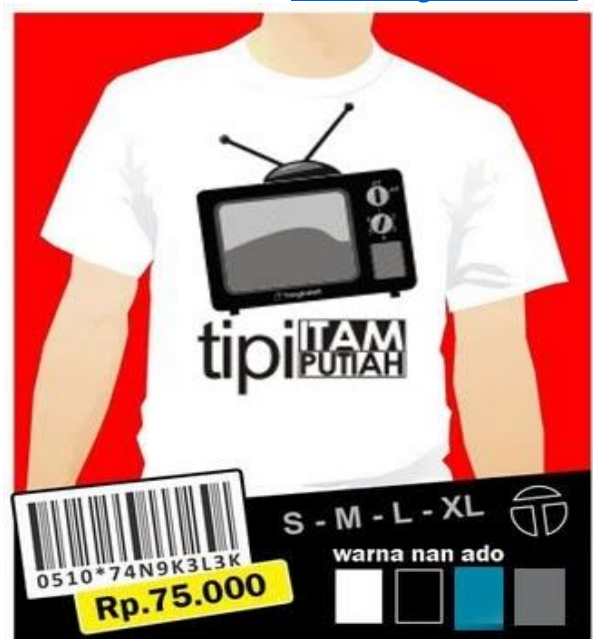

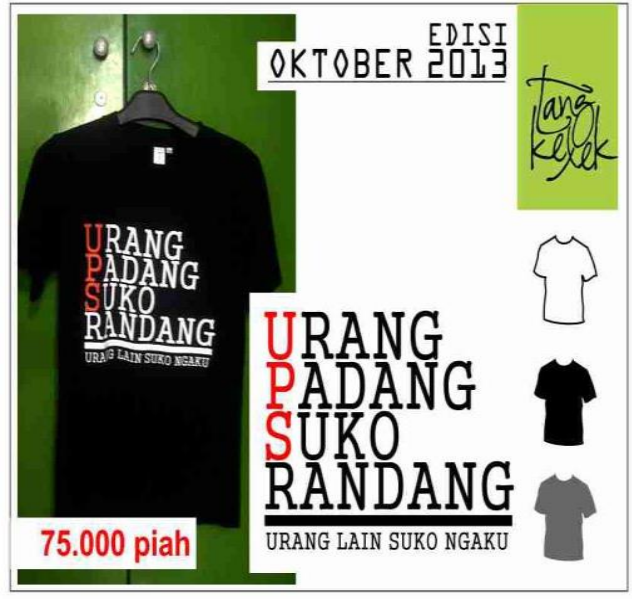

Sumber: $\underline{w w w . t o k o t a k i . c o m}$

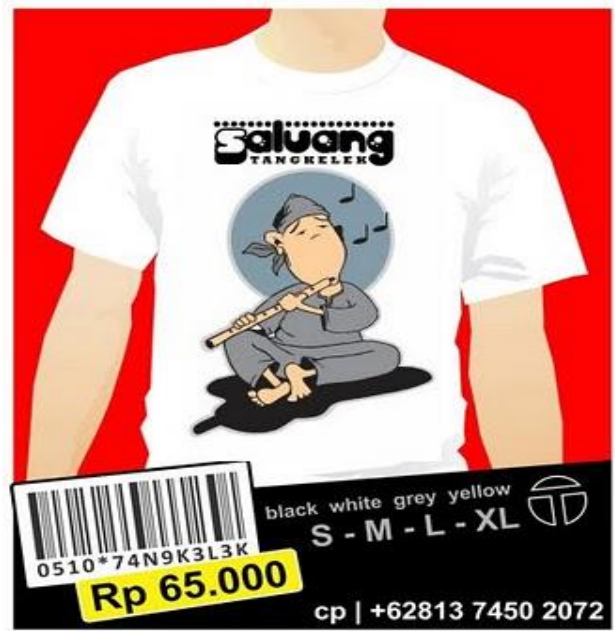

cp | +628137450 2072

Gambar 1. Desain Kaos Kadai Tangkelek

(Sumber : http://tangkelek187.blogspot.com)

Konsep bisnis yang diusung oleh Tangkelek adalah kreatifitas yang mengangkat budaya Minangkabau sebagai sebuah budaya yang kaya akan nilai-nilai positif kehidupan.Istilah Minangkabau sendiri menggambarkan sebuah kebudayaan. Budaya Minangkabau terutama bahasanya digunakan di hampir sebagian besar wilayah Sumatera Barat dan digunakan di beberapa daerah lain yang menjadi tempat perantau Minangkabau berada. Bahasa Minangkabau dipakai di Provinsi Sumatera Barat, di beberapa daerah di perbatasan Provinsi Jambi (sepanjang Sungai Batanghari), di Kabupaten Kampar Provinsi Riau, serta digunakan oleh kelompokkelompok Jamee (Aceh Barat), dan di Negeri Sembilan (Malaysia). Sehingga budaya dan bahasa Minangkabau sendiri telah dikenal dan tersebar di berbagai daerah.

Totalitas dalam penggunaan bahasa Minangkabau dalam setiap produk yang dihasilkan serta aktivitas promosi pemasaran sangat mempengaruhi brand identity Kadai Tangkelek. Hal ini juga menentukan keputusan konsumen untuk tetap menggunakan produk tersebut atau tidak. Sehingga Kadai Tangkelek perlu mengupayakan pembentukan brand identity sebagai kunci pengembangan produk untuk dikenal dan diingat, memberikan nilai fungsional dan emosional, serta sebagai sarana ekspresi diri bagi konsumen dan perusahaan. 
Produk-produk yang dihasilkan dari Kadai Tangkelek adalah baju kaos, sweater atau jaket, serta beberapa asesoris seperti tas dan pin. Dengan mengusung tema budaya Minangkabau dan nilai filosofisnya tersebut, dalam desain produknya Tangkelek menggunakan istilah-istilah, petuah, pepatah dan kiasan-kiasan dalam bahasa Minangkabau seperti "Bakandak tanduak kapado kudo", "Urang awak urang hebat" dan lain-lain yang menjadi daya tarik tersendiri bagi konsumennya.

Berdasarkan observasi awal, terlihat bahwa penjualan Kadai Tangkelek atas produknya meningkat dari tahun ke tahun. Keberhasilan penjualan produk yang semakin meningkat setiap tahunnya ini menyebabkan permintaan akan barang dari Kadai Tangkelek semakin besar. Peningkatan penjualan ini disadari tidak hanya karena kualitas produk yang memuaskan harapan konsumen, akan tetapi Kadai Tangkelek telah mentransformasikan nilai sebagai produk kreatif dan unik, menjunjung nilai-nilai budaya Minangkabau sebagai tema yang diangkat dalam produknya. Komunikasi adalah instrumen penting dalam kehidupan manusia sebagai makhluk sosial. Sebagai proses penyampaian pesan, komunikasi berlangsung dalam setiap aspek kehidupan manusia dalam rangka memenuhi kebutuhannya. Menurut Brelson dan Steiner, komunikasi adalah penyampaian informasi, ide, emosi, keterampilan, dan seterusnya, melalui penggunaan simbol, angka, grafik, dan lain-lain. Manusia sebagai pelaku interaksi dan pengguna informasi memiliki peran yang sama dalam sebuah proses komunikasi.

Menurut Carl I.Hovland dalam Mulyana, komunikasi adalah proses yang memungkinkan seseorang (komunikator) menyampaikan rangsangan (biasanya lambing-lambang verbal) untuk mengubah perilaku orang lain (komunikate). Dalam hal ini komunikasi digunakan sebagai alat untuk mencapai tujuan dari sebuah interaksi. Komunikasi sebagai ilmu multi disiplin diterapkan dalam berbagai bidang seperti dalam kegiatan ekonomi dan perdagangan dengan pemahaman bahwa penggunaan lambing-lambang verbal tersebut merupakan faktor yang menentukan keberhasilan dalam mencapai tujuan kegiatan.

Perdagangan merupakan salah satu kegiatan yang membutuhkan peran proses komunikasi dalam pencapaian tujuan. Keberhasilan transaksi dalam perdagangan dapat dipengaruhi oleh kualitas komunikasi yang terjadi diantara pelakunya. Di samping itu, komunikasi dimanfaatkan sebagai alat untuk melakukan kegiatan promosi dalam bidang kegiatan perdagangan.

Promosi adalah kegiatan komunikasi yang bertujuan untuk memperkenalkan produk atau jasa dalam rangka mencapai tujuan tertentu. Promosi adalah komunikasi dari para pemasar yang menginformasikan, membujuk, dan mengingatkan para calon pembeli suatu produk dalam rangka mempengaruhi pendapat mereka atau memperoleh suatu respons. Tingkat penjualan yang tinggi serta minat konsumen yang tinggi terhadap produk adalah tujuan utama sebuah perusahaan, maka promosi menjadi sebuah proses yang digunakan untuk mencapai tujuan tersebut.

Berkembangnya berbagai bentuk kreatifitas dalam berbagai industri dan di bidang perdagangan menyebabkan persaingan antar pelaku usaha semakin ketat sehingga menuntut produsen untuk memiliki strategi promosi yang lebih efektif dalam memasarkan produk mereka. Produsen tidak hanya terfokus pada bagaimana produk yang dihasilkan dapat terjual atau dibeli 
oleh konsumen akhir dengan tingkat harga yang memberikan keuntungan bagi perusahaan dalam jangka panjang. Produsen lebih berupaya mengarahkan kegiatan pemasaran dengan efisiensi target dan biaya yang tepat guna menarik minat konsumen untuk menggunakan produk yang ditawarkan.

Kegiatan promosi yang optimal dan efisien tidak hanya memberikan dampak signifikan terhadap penjualan produk yang dihasilkan namun dapat meningkatkan minat, kepuasan serta kepercayaan konsumen terhadap produk sehingga dapat memberikan jaminan dan prestise sesuai dengan gaya hidup konsumen. Istilah brand (merek)kemudian muncul sebagai bentukpenguatan peran merekdalam persaingan produk yang semakin ketat dan untuk mengelompokkan produk yang beragam.

Brand merupakan sebuah cara untuk menunjukkan jiwa, nilai - nilai serta identitas perusahaan yang dimaknai bersama oleh konsumen. Brand sebagai atribut perusahaan memberikan nilai, budaya, dan kepribadian tertentu terhadap konsumen. Pentingnya membangun identitas brand (brand identity) disadari atas kemampuannya dalam memberikan jaminan kepuasan dan membantu kemantapan hubungan diantara merek dan konsumen.Brand identity adalah seperangkat kombinasi dari komponen visual, suara, tema produk, gerak dan hal - hal lain yang dipakai dalam merancang strategi komunikasi guna melakukan promosi serta menjadi pembeda produk yang memiliki ciri khas dari produk pesaing produsen. Identitas sebuah brand diwujudkan dengan mengangkat sebuah konsep atau tema yang menjadi ciri khas dari produk itu sendiri. Secara garis besar tema merupakan ide pokok yang dipersoalkan dalam sebuah karya, seni, atau produk.

Kadai Tangkelek adalah salah satu kegiatan usaha di bidang industri kreatif yang berfokus pada fashion. Secara bertahap Tangkelek mengupayakan brand identity dari merek perusahaan. Tangkelek dimulai dengan konsep melestarikan budaya Minangkabau sebagai ide dasar untuk produknya yang menonjolkan kearifan budaya lokal sebagai icon. Kadai Tangkelek telah dikenal luas oleh sebagian besar konsumen dari Kota Padang dan juga wisatawan baik domestik maupun mancanegara yang berkunjung ke Sumatera Barat.

\section{METODE PENELITIAN}

Metode penelitian pada penelitian menggunakan metode kualitatif. Penelitian kualitatif bertujuan untuk menjelaskan fenomena dengan sedalam-dalamnya. Riset ini tidak mengutamakan besarnya populasi atau sampling bahkan populasi atau sampling-nya sangat terbatas. Populasi yang digunakanadalah informan dari pihak internal Tangkelek seperti pemilik, manager, karyawan, distributor/reseller serta konsumen Tangkelek sebagai triangulasi data. Sampel dalam penelitian ini untuk mendapatkan informan penelitian menggunakan metode purposive sampling, sampel yang didapat 5 orang informan. Teknik pengumpulan data yang digunakan peneliti ada beberapa cara yaitu: observasi, wawancara, dan dokumentasi. Analisis data kualitatif pada penelitian ini menggunakaan model analisis yang dicetuskan oleh Miles dan Haberman yang sering disebut metode analisis interaktif. Analisis ini terdiri dari tiga alur 
kegiatan yang secara bersamaan yaitu reduksi data (reduction data), penyajian data (display data), penarikan serta pengujian kesimpulan (drawing and verifying conclusion)

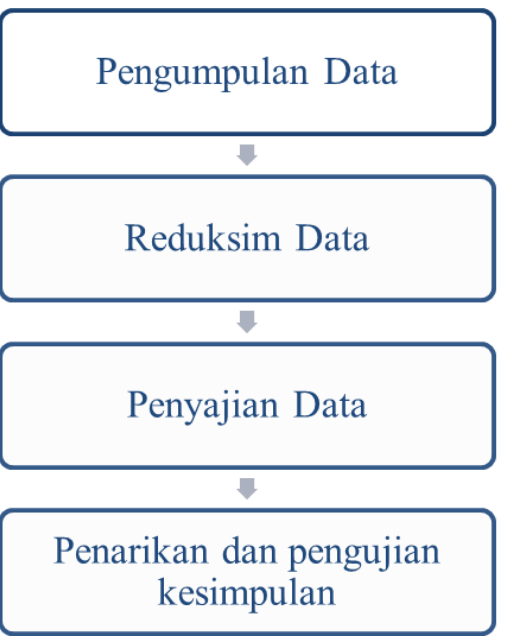

Gambar 2. Analisis Data Kualitatif Menurut Miles dan Huberman (Sumber: Sugiyono, 2005:92)

\section{HASIL DAN PEMBAHASAN}

\section{Komunikasi Promosi Tangkelek Pada Tema Produk Dalam Membangun Pesan Terhadap Konsumen}

Branding ekternal yang dilakukan oleh Distro Tangkelek secara umum menggunakan media online yang dibuat dan kelola secara langsung oleh pihak internal Distro Tangkelek, yaitu dengan dengan penggunaan website dan media sosial seperti berikut ini :

1. Website

Sistem pengaksesan informasi dalam Internet yang paling terkenal adalah World Wide Web (www) atau biasa dikenal dengan istilah website. Pertama kali diciptakan tahun 1991 di CERN, tujuan awalnya adalah untuk menciptakan media yang mudah untuk berbagi informasi diantara para fisikawan dan ilmuwan (Kadir, 2008:375). Laudon (2007:133) menjelaskan bahwa website adalah perpustakaan online mengenal informasi pelanggan selain menjadi pasar dimana barang dan jasa dibeli. Website memiliki pengaruh luar biasa pada pembelian offline. Hal tersebut juga diterapkan olehDistro Tangkelek, yakni menggunakan website sebagai alat komunikasi dan promosi produk. Berikut ini tampilan website Distro Tangkelek: 


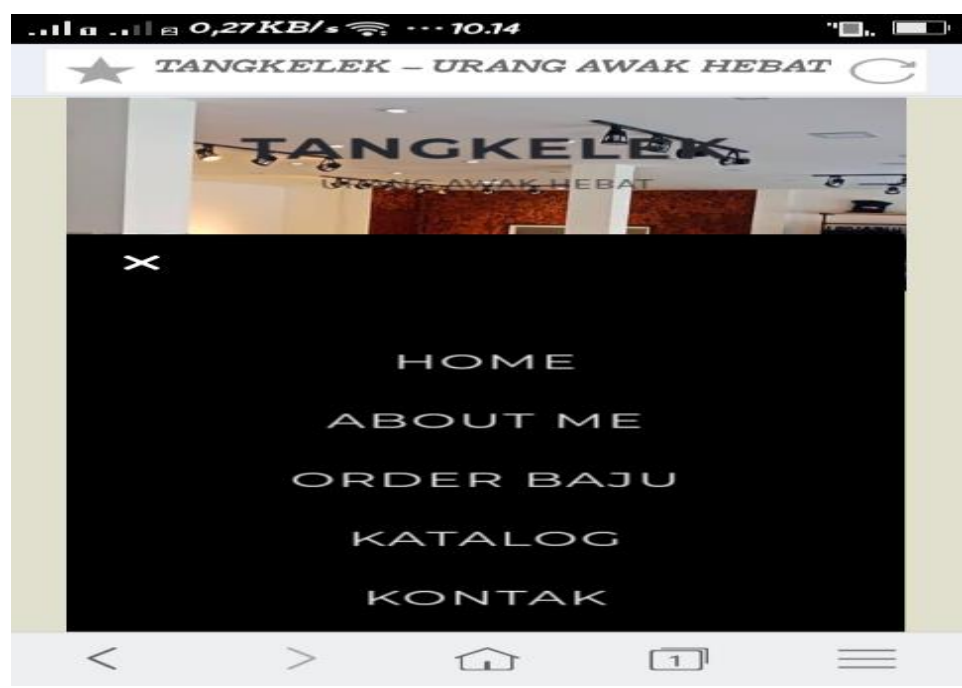

Gambar 8. Tampilan website Tangkelek

Penggunaan website Distro Tangkelek sejauh ini sudah digunakan secara maksimal, hal ini terlihat dengan seringnya admin website tangkelek memuat informasi atau update seputar produk mereka. Sejauh ini, website Distro Tangkelek cukup membantu proses penjualan dan meningkatkan pendapatan.

2. Instagram

Saking populernya Instagram sebagai sebuah media sosial, banyak orang yang tak tahu arti sebenarnya dari pemakaian kata tersebut. Disusun dari dua kata, yaitu "Insta" dan "Gram". Arti dari kata pertama diambil dari istilah "Instan" atau serba cepat/mudah. Namun dalam sejarah penggunaan kamera foto, istilah "Instan" merupakan sebutan lain dari kamera Polaroid. Yaitu jenis kamera yang bisa langsung mencetak foto beberapa saat setelah membidik objek. Sedangkan kata "Gram" diambil dari "Telegram" yang maknanya dikaitkan sebagai media pengirim informasi yang sangat cepat. Jadi instagram digunakan sebagai media untuk membuat foto dan mengirimkannya dalam waktu yang sangat cepat. Tujuan tersebut sangat dimungkinkan oleh teknologi internet yang menjadi basis aktivitas dari media sosial ini.

Agar tetap terhubung dengan dengan konsumen ataupun menjangkau konsumen baru, Distro Tangkelek turut aktif di instagram hngga saat ini. Akun ini telah memiliki followers atau pengikut sebanyak 46,4 ribu followers. Berikut ini tampilan akun instagram Distro Tangkelek : 


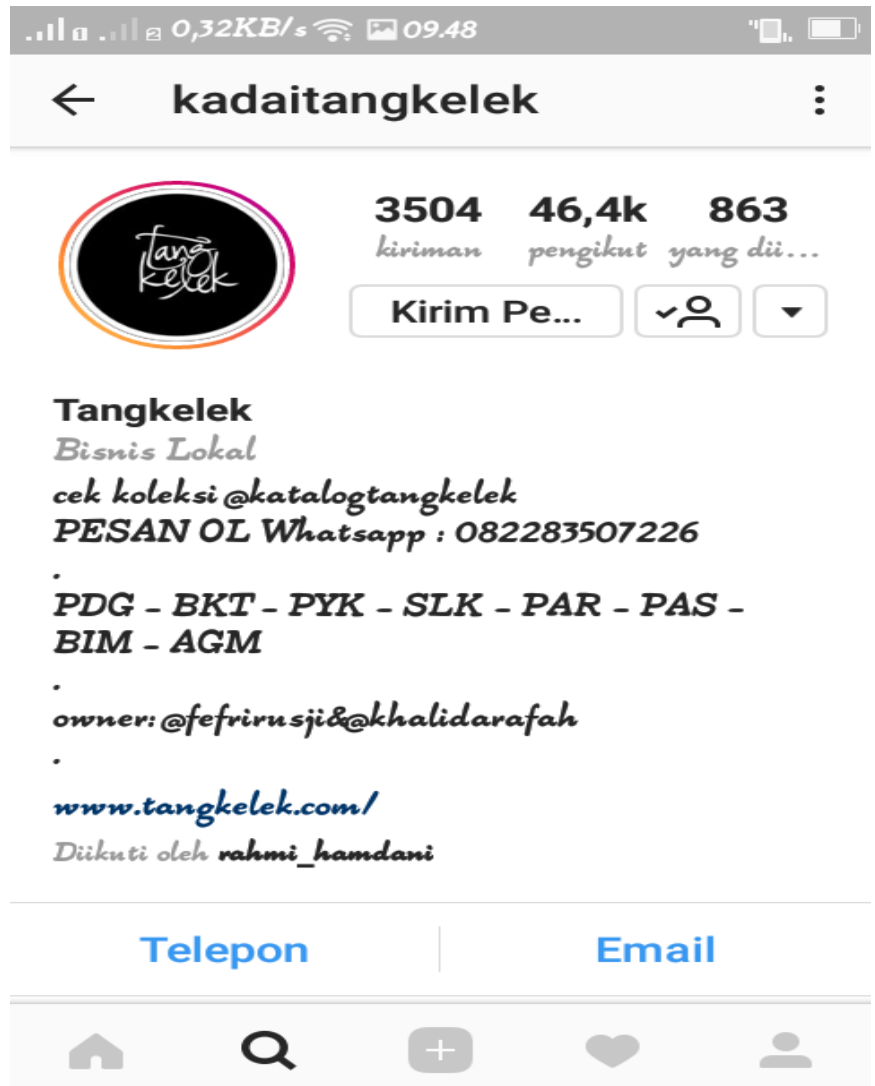

3. Facebook

Gambar 9. Tampilan Instagram Tangkelek

Layanan jejaring sosial yang mulai diluncurkan pada Febuari 2004 ini telah berhasil menempatkan diri sebagai salah satu situs yang sangat digemari dan meiliki jumlah penggun yang meningkat setiap tahunnya. Pada tahun 2019 facebook memiliki lebih dari 2,38 miliar pengguna aktif di seluruh dunia. Data yang dilansir dari situs resmi Kemenkominfo RI menyebutkan bahwa hasil survei yang dilakukan oleh Webershandwick, perusahaan public relations dan pemberi layanan jasa komunikasi, untuk wilayah Indonesia terdapat sekitar 120juta pengguna facebook aktif.

Distro Tangkelek memanfaatkan media sosial ini untuk tetap berhubungan dengan konsumen dan menjangkau konsumen baru. Dari semua media sosial yang dimiliki Distro Tangkelek, facebook merupakan salah satu media sosial yang cukup aktif dalam memuat informasi terbaru mengenai produk. Akun facebook dalam bentuk fanspage ini telah memiliki likes sebanyak 5.962, berikut ini tampilan akun facebook Distro Tangkelek: 


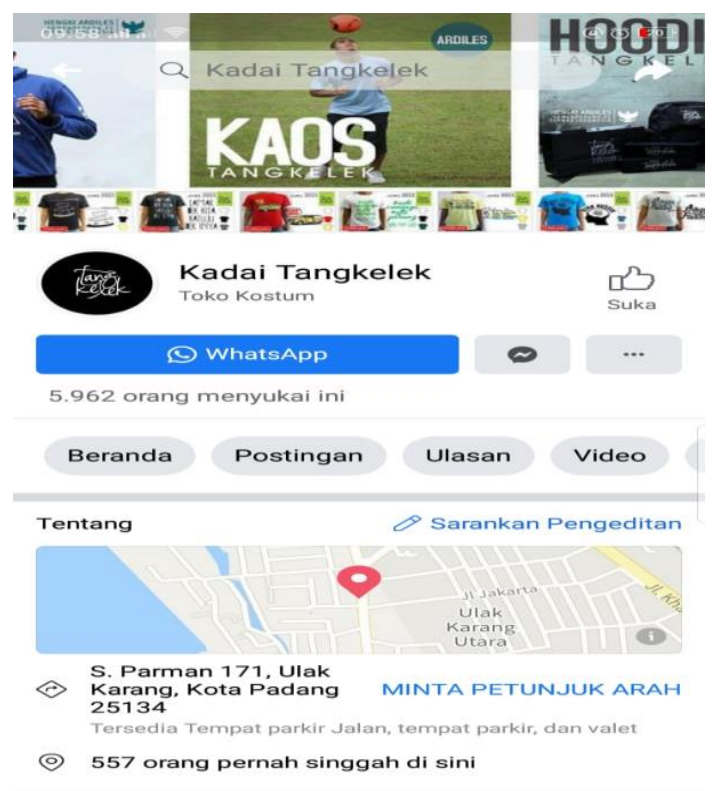

Gambar 10. Facebook Tangkelek

Pembentukan Brand Identity Tangkelek Melalui Aktivitas Promosi dan Penggunaan Budaya Minangkabau

\section{Brand Identity}

Merek merupakan nama, istilah, tanda, simbol desain, ataupun kombinasi yang mengidentifikasi suatu produk/jasa yang dihasilkan oleh suatu perusahaan. Identifikasi tersebut juga berfungsi untuk membedakannya dengan produk yang ditawarkan oleh perusahaan pesaing. Lebih jauh, sebenarnya merek merupakan nilai tangible dan intangible yang terwakili dalam sebuah trademark (merek dagang) yang mampu menciptakan nilai dan pengaruh tersendiri dipasar bila diatur dengan tepat. (Durianto, Sugiarto, and Sitinjak, 2004: 1)

Brand (merek) merupakan salah salah satu bagian terpenting dari suatu produk. Merek dapat menjadi suatu nilai tambah bagi suatu produk,baik itu berupa barang atau jasa. Nilai tambah ini sangat menguntungkan bagi produsen atau perusahaan. Karena itulah perusahaan berusaha terus memperkenalkan merek yang dimilikinya dari waktu ke waktu, terutama konsumen yang menjadi target marketnya.Merek merupakan nama yang dapat dihubungkan/diasosiasikan dengan satu atau lebih barang atau hal yang berada didalam lini produk yang digunakan untuk mengenali sumber atau ciri barang/hal tersebut (Kotler, 1992: 92).

\section{Strategi Branding}

Branding merupakan suatu keharusan untuk dilakukan karena banyaknya persaingan sekarang ini dimana konsumen menghadapi banyak pilihan dan kualitas produk yang dihadapkan sehingga sulit untuk dibedakan. Branding mengacupada proses komunikasi dalam penciptaan suatu brand, dengan katalain branding adalah proses penciptaan merek. Branding yang dilakukan dapat menguatkan image produk dibenak konsumen dan menciptakan diferensiasi dibandingkan 
brand lain yang mempunyai karakteristik hampir sama (Janita,2009:1).

Strategi branding merupakan sebuah kebijakan untuk membuat dan memelihara secara berkelanjutan keuntungan kompetitif. Terdiri dari pengembangan dan pemeliharaan atribut dan nilai produk yang koheren, tepat, khas, dapat dilindungi dan menarik bagi pelanggan. Aplikasi yang kreatif dari instrument branding seperti paten, merek dagang, nama, simbol, dan logo bisa meningkatkan pasar. Nama brand merepresentasikan komunikasi yang kuat antara perusahaan dan pasar. Sebuah brand harus bisa mengkomunikasikan kompetensi dan kapasitas mereka untuk menawarkan keunggulan nilai kepada konsumen, dibandingkan dengan pesaing mereka dengan menbangun reputasi mereka dengan brand sebagai fokus hasil akhir mereka (Abimbola, 2001:100).

\section{Brand Identity}

Membangun brand identity (identitas merek) menjadi hal yang penting ketika konsumen dihadapkan pada banyaknya pilihan untuk produk sejenis yang ditawarkan dipasaran. Merek berkaitan dengan penambahan atau pengurangan nilai yang diberikan sebuah produk kepada perusahaan dan pelanggan.

Identitas merekadalah seperangkat asosiasi merek yang unik yang diciptakan oleh para penyusun strategi merek. Asosiasi-asosiasi ini mencerminkan kedudukan suatu merek dan merupakan suatu janji kepada pelanggan dari anggota organisasi. Identitas merek akan membantu kemantapan hubungan diantara merek dan pelanggan melalui proposisi nilai yang melibatkan manfaat fungsional, manfaat emosional atau ekspresi diri. (Kotler \& Keller, 2006:261).

\section{Elemen Brand}

Elemen brand adalah upaya visual bahkan kadangkala fisik yang bertindak mengidentifikasi dan mendeferensiasi suatu produk atau jasa perusahaan. Elemen brand formal seperti nama, jenis logo, dan slogan bersatu membentuk identitas visual suatu brand atau perusahaan. (Kotler \& Pfoertsch, 2008). Beberapa elemen brand identity adalah sebagai berikut (jurnal Clementina dkk, 2014: 2) :

\section{a. Nama Brand}

Nama brand adalah yang pertama dan mungkin ekspresi terbesar atau wajah dari suatu produk. Nama yang dipilih dengan baik untuk suatu perusahaan, produk, atau jasa dapat menjadi aset berharga, seperti halnya brand itu sendiri.

b. Logo

Logo adalah tampilan grafis dari nama brand atau perusahaan. Kekuatan simbol tidak boleh dianggap remeh "karena manusia cenderung menjadi lebih mudah menerima citra dan simbol, logo yang kuat dapat memberi kohesi dan membangun kesadaran identitas brand, memudahkan pengenalan dan ingatan kembali”. 
c. Kisah Merek

Kisah dapat menjadi lebih penting dalam kehidupan perusahaan. Sebagai suatu konsep, kisah merek menjadi tolak ukur penting dalam menentukan langkah-langkah strategis brand di masa yang akan datang.

\section{KESIMPULAN}

Berdasarkan identifikasi masalah dan hasil penelitian yang telah dilakukan, maka dapat diperoleh kesimpulan bahwa Distro Tangkelek merupakan salah satu Distro yang menjual produk yang melakukan branding. Komunikasi promosi yang dilakukan Distro Tangkelek untuk menyampaikan pesan kepada konsumen dilakukan dengan beberapa cara. Diantaranya promosi melalui website, instagram dan facebook. Sejauh ini pepatah atau guyonan yang di desain pada produk terutama baju kaos menarik minat pembeli untuk membeli produk tersebut. Menurut pembeli kata-kata atau guyonan pada produk tersebut bisa dikatakan lucu dan mengandung pesan dan nilai-nilai falsafah kebudayaan masyarakat minangkabau.

Salah satu komunikasi dilakukan melalui promosi produk adalah dengan menciptakan brand yang unik untuk membangun kekhasan produk dimata dan benak masyarakat. Brand tersebut menggambarkan bahwa Distro Tangkelek adalah produk dengan ciri khas yang mengusung tema dan falsafah hidup masyarakat minangkabau.

Dari berbagai upaya promosi yang dilakukan, media instagram menduduki peringkat pertama sebagai media yang berhasil menyampaikan pesan brand poduk kepada para pembeli. Hal ini terlihat dengan banyaknya followers instagram dari @kadaitangkelek yang menyukai produk-produk yang diposting.Selain itu media berupa website dan facebook juga memiliki pengaruh yang cukup signifikan terhadap hasil penjualan produk Distro Tangkelek.

\section{REFERENSI}

Arifin, Anwar. 1998. Ilmu Komunikasi : Sebuah Pengantar Ringkas. Jakarta : PT Raja Grafindo Persada

Afifuddin dan Saebani, Beni Ahmad. 2009. Metodologi Penelitian Kualitatif. Bandung: CV Pustaka Setia

Alifahmi,Hifni. 2005. Sinergi Komunikasi Pemasaran: Integrasi Iklan, Public relation, dan Promosi. Jakarta: Quantum

Assauri, Sofjan. 2011. Manajemen Pemasaran : Dasar, Konsep, dan Strategi. Jakarta: PT Raja Grafindo Persada

Dewi, Ike Janita. 2009. Creating \& Sustaining Brand Equity. Yogyakarta: Asmara Books

Durianto,Darmadi, Sugiarto, dan Sitinjak, T. 2004. Strategi menaklukan Pasar : Melalui Riset Ekuitas dan Perilaku Merek, Jakarta: PT Gramedia Pustaka Utama 
Fajar M. 2009. Ilmu Komunikasi Teori Dan Praktik. Yogyakarta: Graham Ilmu

Harris, Thomas L. 1991. The Marketer's Guide To Public Relations. New York : John Wiley \& Sons, Inc.1998. Value Added Public Relations - The Secret Weapon of Integrated Marketing. NTC Business Books

Gelder, gmS.V. 2005. Global Brand Strategy. London: Konan Page

Kadir, Abdul. 2008. Dasar Pemrograman Web Dinamis menggunakan PHP. Yogyakarta: Andi

Kasmir. 2004. Pemasaran Bank, Jakarta: Prenada Media

Knapp, Duane. E. 2001. The Brand Mindset. Yogyakarta : Andi Offset. Sulaksana, Uyung. 2003 . Ilmu Komunikasi : Teori dan Praktek. Bandung: Remaja Rosdakarya

Kotler, Philip, dan Kevin L, Keller. 2007. Manajemen Pemasaran Edisi 12, (Benyamin Molan.Terjemahan). Jakarta: PT Indeks

Kottler, Keller. 2006. Manajemen Pemasaran: analisis, perencanaan dan pengendalian jilid 3, Jakarta: Erlangga

Kottler, Philip. 1992. Manajemen Pemasaran: analisis, perencanaan dan pengendalian jilid 2, Jakarta: Erlangga

Kriyantono, Rachmat. 2010. Teknik Praktis Riset Komunikasi. Jakarta: Kencana Prenada Media Group

Lamb, Charles W, Joseph F. Hair, Carl McDaniel. 2001. Marketing 5th . Jakarta : Salemba Empat Laudon, Kenneth .C, Jane P. Laudon. 2007. Sistem Informasi Manajemen Edisi ke10. Terjemahan Chriswan Sungkono dan Machmudin Eka.P. Jakarta : Salemba Empat

Mulyana, Deddy. 2009. Ilmu Komunikasi Suatu Pengantar. Bandung : PT Remaja Rosdakarya Offset

Moleong, Lexi J. 2004. Metodologi Penelitian Kualitatif. Bandung: PT Remaja Rosdakarya

Nurjaman, Kadar dan Khaerul Umam. 2012. Komunikasi \& Public Relations. Bandung: CV Pustaka Setia.

Patton, Michael Quinn. 1987. Qualitative Evaluation Methods. Biverly Hill: Sagc Publication

Pawito. 2008. Penelitian Komunikasi Kualitatif. Yogyakarta: PT.LKIS Pelangi Aksara

Rambat Lupiyoadi, A.Hamdani. 2006. Manajemen Pemasaran Jasa. Jakarta: Salemba Empat.

Rangkuti, Freddy. 2009. Strategi Promosi yang Kreatif dan Analisis Kasus Integrated Marketting Communication. Jakarta: PT Gramedia Pustaka Utama 
Ruslan, Rosady. 2001. Manajemen Humas \& Manajemen Komunikasi : Konsep dan Aplikasi. Jakarta : Rajawali Pers

Saputra, Wahidin dan Rully Nasrullah. 2011. Public Relation 2.0 (Teori dan Praktik Public Relations di Era Cyber). Jakarta : Pramata Publishing

Setiadi, Nugroho J. 2003 . Perilaku Konsumen: Konsep dan Implikasi untuk Strategi dan Penelitian Pemasaran. Jakarta: Kencana Prenada Media Group

Shimp, A Terence. 2003. Promosi dan Periklanan: Aspek Tambahan Komunikasi Pemasaran Terpadu. Jakarta: Erlangga

Soehadi, Agus W. 2005. Effective Branding. Bandung: Quantum Bisnis dan Manajemen

Sugiyono, 2008. Metode Penelitian Kuantitatif Kualitatif dan R\&D. Bandung: Alfabeta

Sugiyono, 2010. Metode Penelitian Kuantitatif Kualitatif dan R\&D. Bandung: Alfabeta

Sulaksana, Uyung. 2003. Integrated Marketing Communications. Yogyakarta: Pustaka Pelajar

Sutisna. 2001 . Perilaku Konsumen \& Komunikasi Pemasaran. Bandung: Remaja Rosdakarya

Swastha, Basu. 2007. Pengantar Bisnis Modern, Edisi ketiga, Cet ke-11.Yogyakarta: Liberty Yogyakarta

Tjiptono,Fandy, Chandra,Gregorius, dan Adriana, Dadi. 2008. Pemasaran Strategik. Yogyakarta: Andi

Wirasasmita.2002.Kamus Lengkap Ekonomi, Bandung: Pionir Jaya 